\title{
Fodder Yield and Economics as Influenced by Integrated Nutrient Management on Fodder Dual Purpose Oat (Avena sativa)
}

\author{
Vikram Shiyal*, H. K. Patel, C. H. Raval, M. K. Rathwa, P. S. Patel and H. K. Patel \\ Department of Agronomy, B. A. College of Agriculture, Anand Agricultural University, \\ Annad-388110 (Gujarat), India \\ *Corresponding author
}

\section{Keywords \\ INM, FYM, Castor cake, Neem cake, Poultry manure, Biofertilizer, Net realization}

\section{Article Info}

Accepted:

25 October 2020

Available Online:

10 November 2020

\section{A B S T R A C T}

\begin{abstract}
The present research work in entitled "Effect of integrated nutrient management on yield and quality of dual purpose fodder oat (Avena sativa L.)" was carried out during rabi season 2019-20 at Main Forage Research Station, Anand Agricultural University, Anand. The soil of experimental unit was loamy sand in texture (locally called as "Goradu" soil) with low in organic carbon $(0.28 \%)$ and available nitrogen $(232.87 \mathrm{~kg} / \mathrm{ha})$, while medium in phosphorus $(35.12 \mathrm{~kg} / \mathrm{ha})$ and medium to high in potassium $(280.20 \mathrm{~kg} / \mathrm{ha})$ with 7.46 $\mathrm{pH}$ and EC $0.21 \mathrm{dS} / \mathrm{m}$. The experiment encompassed of ten different INM treatments and it was laid out in randomized block design with four replications. The details of treatments are as follows, $\mathrm{T}_{1}(100 \% \mathrm{RDF}), \mathrm{T}_{2}(10 \mathrm{t} \mathrm{FYM}+100 \% \mathrm{RDF}), \mathrm{T}_{3}$ (Castor Cake $+100 \%$ $\mathrm{RDF}), \mathrm{T}_{4}$ (Poultry Manure $\left.+100 \% \mathrm{RDF}\right), \mathrm{T}_{5}$ (Neem Cake + 100\% RDF), $\mathrm{T}_{6}(5 \mathrm{t} \mathrm{FYM}+$ $25 \% \mathrm{~N}$ from FYM $+75 \% \mathrm{RDF}+$ Bio-fertilizer), $\mathrm{T}_{7}(5 \mathrm{t} \mathrm{FYM}+25 \% \mathrm{~N}$ from Castor Cake+ $75 \%$ RDF + Bio-fertilizer), $\mathrm{T}_{8}(5 \mathrm{t}$ FYM $+25 \% \mathrm{~N}$ from Poultry Manure+ $75 \% \mathrm{RDF}+$ Biofertilizer), $\mathrm{T}_{9}(5 \mathrm{t} \mathrm{FYM}+25 \% \mathrm{~N}$ from Neem Cake+ $75 \% \mathrm{RDF}+$ Bio-fertilizer $)$ and $\mathrm{T}_{10}$ $(50 \% \mathrm{~N}$ from $\mathrm{FYM}+50 \% \mathrm{~N}$ from Castor Cake + Bio-fertilizer).The analyzed results of the experiments revealed that, plant population per meter row length at 20 DAS and test weight of oat failed to gave this significant difference due to different INM treatments. The growth and yield attributes of oat crops viz., periodical plant height at 20 and 55 DAS as well as at harvest, number of tillers per meter row length at 55 DAS and at harvest, green forage yield at 55 DAS (first cut), seed yield, straw yield and harvest index were significantly affected by different of treatments INM and recorded significantly higher by application of $5 \mathrm{t} \mathrm{FYM}+25 \% \mathrm{~N}$ from FYM $+75 \% \mathrm{RDF}+$ Bio-fertilizer and also it was found superior by obtaining maximum net realization with its BCR.
\end{abstract}

\section{Introduction}

India is an agricultural country with $2 / 3^{\text {rd }}$ of its rural population depending on it for their livelihood. Livestock is sub-sector of agriculture and in Indian agriculture animal husbandry is closely linked with crop production program as a complementary enterprise which contributes about 4.5 per cent to total GDP and 25.8 per cent to the agriculture GDP (Anon., 2017). Convivial feed and fodder has been identified as one of 
the major components in achieving the desired level of livestock production therefor productivity and availability of good quality feed and fodder is of prime importance for the development of livestock sector. India has the largest livestock population, around 15 per cent of the world's livestock population but country has only 4.4 per cent of its cultivated area covered under fodder crops with an annual total forage production of 866 MT (400 MT green fodder production and 466 MT dry fodder production). However, the annual forage requirement is 1706 MT (1097 MT green fodder production and 609 MT dry fodder production) to support the existing livestock population (Rathod and Dixit, 2019). Fodder and crop residues of cereals are major source of forage but the nutritive value of these fodder are not adequate to achieve higher milk production. As a result, livestock suffers continuously with malnutrition for the year round in general, resulting in their production capacity at sub-optimum level and half of the total losses in livestock productivity are due to inadequacy in supply of feed and fodder. Availability of green forage yield for the animal is the key to success of dairy enterprises as it is difficult to maintain health and production of the livestock without supply of green fodder. Under such type of circumstance the only way to bridge the gap between demand and supply of the fodder is to ameliorate the forage resources.

There are several factors which affect the crop production. Among various factors of crop production, proper management of fertilization plays a pivotal role in increasing the oat production after variety and irrigation. Optimum fertilizer application either in form of organic or inorganic is one of the wellestablished techniques for increasing crop production. Although, chemical fertilizers play a crucial role to meet the nutrients requirement of the crop, continuous, inadequate and the imbalance use has adverse effect on the physical, chemical and biological properties of soil thus affecting the sustainability and crop production, besides causing environmental pollution (Virmani, 1994). Consumption of chemical fertilizers will also be quite a limiting factor of agricultural production in future. Because of escalating energy cost, chemical fertilizers are not available at affordable price to the farmers in future (Alim, 2012). Therefore, there is an urgent need to reduce the usage of chemical fertilizers and in turn increase the usage of organics is needed to check the yield and quality levels. On the other hand, use of organics alone will not show in spectacular increase in crop yields, due to their low nutrient status. So, integrated nutrient management is alternate system to gain optimum production without adverse effect on soil. The basic concept of integrated nutrient management refers to the maintenance of soil fertility and plant nutrient supply at an optimum level for sustaining the desired productivity through optimization of the benefits from all possible sources of organic, inorganic and biological components in an integrated manner. Integration of organic manures and inorganic fertilizer materials has been found to be promising not only in maintaining higher productivity of crops but also for providing stability in crop production, and improving soil physical conditions (Verma et al., 2012).

\section{Materials and Methods}

In order to achieve the pre-set objectives of the present exploration, a field experiment was conducted during the rabi season of the year 2019-20 on plot no. A-15 at Main Forage Research Station, Anand Agricultural University, Anand (Gujarat). The experimental site had an even topography with moderate slope and good drainage as well as the soil is representative of the soils of 
the region, popularly known as "Goradu" soil. It is loamy sand texture and alluvial in origin. The soils are very deep and fairly moisture retentive. Soils respond well to manuring and irrigation. They are suitable to variety of crops of tropical and sub-tropical regions. Data on initial soil analysis indicated that the experimental site was low in organic carbon $(0.28 \%)$ and available nitrogen $(232.87 \mathrm{~kg} / \mathrm{ha})$, while medium in available phosphorus (35.12 kg/ha) and medium to high in potassium $(280.20 \mathrm{~kg} / \mathrm{ha})$. The present experiment was laid out in randomized block design with ten combinations of organic, inorganic and biofertilizer with four replications. From RDF, half quantity of nitrogen in the form of urea and entire quantity of phosphorus in the form of SSP was supply to the oat crop as basal and the remaining half quantity of nitrogen was given in two equal splits, first at 40 DAS and second at first cut (55 DAS). The entire quantity of organic manure, FYM, neem cake, poultry manure, and castor cake was applied before 10 days of sowing and biofertilizer (NPK consortia) was spray in field at time of sowing@11/ha. From 10t FYM/ha equivalent $\mathrm{N}$ was applied in $\mathrm{T}_{3}$ (Castor Cake $+100 \%$ RDF), $\mathrm{T}_{4}$ (Poultry Manure $\left.+100 \% \mathrm{RDF}\right), \mathrm{T}_{5}$ (Neem Cake $+100 \%$ RDF)with respective sources. The collected data for various parameters were statistically analyzed using Fishers analysis of variance (ANOVA) technique and the treatments were compared at 5\% levels of significance (Cochran and Cox, 1967). All the observation, growth and yield parameter was taken as per standard method.

\section{Results and Discussion}

\section{Plant population per meter row length}

An examination of data given in Table 1revealed that plant population of oat recorded at 20 DAS was not significantly influenced by different treatments of INM. It indicated that the differences in the results of the parameters were obtained due to treatments effect only. Similar results were also observed by Patel et al., (2016).

\section{Periodical plant height $(\mathrm{cm})$}

Application of $5 \mathrm{t}$ FYM $+25 \% \mathrm{~N}$ from FYM + $75 \% \mathrm{RDF}+$ Bio-fertilizer $\left(\mathrm{T}_{6}\right)$ was recorded significantly taller plant at 20 DAS (26.25 $\mathrm{cm})$, at 55 DAS $(129.25 \mathrm{~cm})$ and tallest plant at harvest $(112.30 \mathrm{~cm})$ among the all INM treatments. Plant height was significantly increase under INM due to combine application of organic and inorganic fertilizer with biofertilizer increased availability of essential macro and micro nutrient throughout the crop period and increase their compatibility. The availability of nitrogen INM affected photosynthesis, path of creating food for plant resultant formation of new cells and their development which ultimately affected plant height. These findings are in contrast with the results of Ahmad et al., (2011) and Jadav et al., (2018).

\section{Number of tillers per meter row length}

The results of data presented in Table 1, number of tillers per meter row length of oat at 55 DAS and at harvest revealed that application of $5 \mathrm{t} F Y M+25 \% \mathrm{~N}$ from FYM + $75 \%$ RDF + Bio-fertilizer $\left(\mathrm{T}_{6}\right)$ noted significantly higher number of tillers per meter row length (127.65) but did not differs significantly with treatment $\mathrm{T}_{7}(5 \mathrm{t} \mathrm{FYM}+$ $25 \% \mathrm{~N}$ from Castor Cake $+75 \% \mathrm{RDF}+\mathrm{Bio}-$ fertilizer), $\mathrm{T}_{8}(5 \mathrm{t} \mathrm{FYM}+25 \% \mathrm{~N}$ from Poultry Manure $+75 \%$ RDF + Bio-fertilizer) and $\mathrm{T}_{9}$ $(5 \mathrm{t}$ FYM $+25 \% \mathrm{~N}$ from Neem Cake $+75 \%$ $\mathrm{RDF}+$ Bio-fertilizer) at 55 DAS and significantly the highest number of tillers per meter row length (149.50) at harvest reported in $5 \mathrm{t} \mathrm{FYM}+25 \% \mathrm{~N}$ from FYM $+75 \% \mathrm{RDF}$ + Bio-fertilizer $\left(\mathrm{T}_{6}\right)$. Significantly lower number of tillers per meter row length was 
observed under $\mathrm{T}_{10}(50 \% \mathrm{~N}$ from $\mathrm{FYM}+50 \%$ $\mathrm{N}$ from Castor Cake + Bio-fertilizer) at 55 DAS (114.65) and at harvest (121.0). Nitrogen through INM being act as a chief promoter of growth leading to higher photosynthetic activity which might have responsible for improvement leafiness percentage. The leafiness percentage increased significantly with increased availability of nitrogen and leafiness is directly affected number of tillers per meter row length. Numbers of cuts also influence the number of tillers, which could be the result of efficient utilization of natural resources likewise, light, water as well as nutrient and minimum competition between the plants (Jayanthi et al., 2002).

\section{Green fodder yield at 55 DAS (q/ha)}

Perusal of data presented in Table 1 revealed that green fodder yield of oat at 55 DAS was significantly influenced by different treatments of INM and recorded significantly higher green fodder yield (546 q/ha) under treatment $\mathrm{T}_{6}(5 \mathrm{t} \mathrm{FYM}+25 \% \mathrm{~N}$ from FYM + $75 \%$ RDF + Bio-fertilizer). However, it was remained at par with the all other treatments except $\mathrm{T}_{10}(50 \% \mathrm{~N}$ from $\mathrm{FYM}+50 \% \mathrm{~N}$ from Castor Cake + Bio-fertilizer) and $\mathrm{T}_{3}$ (Castor Cake $+100 \%$ RDF). Significantly the lowest green fodder yield (406 q/ha) was also recorded under treatment $\mathrm{T}_{10}(50 \% \mathrm{~N}$ from $\mathrm{FYM}+50 \% \mathrm{~N}$ from Castor Cake + Biofertilizer). It maybe suggested that plants under this combination of INM developed healthy roots and enabled plant to absorb more moisture and nutrient relatively from lower strata due to use of organic and inorganic fertilizer with biofertilizer and also probably from higher tension by increasing with the depth of roots proliferation in soil, which has in turn improved growth parameter and its directly influenced the green fodder yield. This results are collaborate to Chandra and Ram, (2007) and Sheoran and Rana, (2005).

\section{Seed yield (kg/ha)}

It was evident from data presented in Table 1 that INM treatments exerted their valuable impact on seed yield of oat. Among the different INM treatments, $5 \mathrm{t} \mathrm{FYM}+25 \% \mathrm{~N}$ from FYM + 75\% RDF + Bio-fertilizer $\left(\mathrm{T}_{6}\right)$ recorded significantly higher seed yield (2523 $\mathrm{kg} / \mathrm{ha}$ ) but it remain at par with treatment $\mathrm{T}_{7}$ $(5 \mathrm{t} \mathrm{FYM}+25 \% \mathrm{~N}$ from Castor Cake $+75 \%$ $\mathrm{RDF}+$ Bio-fertilizer $), \mathrm{T}_{8}(5 \mathrm{t} \mathrm{FYM}+25 \% \mathrm{~N}$ from Poultry Manure $+75 \% \mathrm{RDF}+\mathrm{Bio}-$ fertilizer) and $\mathrm{T}_{9}(5 \mathrm{t} \mathrm{FYM}+25 \% \mathrm{~N}$ from Neem Cake $+75 \%$ RDF + Bio-fertilizer). Significantly lower seed yield (1644 kg/ha) was recorded in treatment $\mathrm{T}_{2}(10 \mathrm{t} \mathrm{FYM}+$ $100 \%$ RDF). Increase higher seed yield recorded higher with application of 5t FYM + $25 \% \mathrm{~N}$ from FYM $+75 \% \mathrm{RDF}+$ Biofertilizer might be due to the better effect of availability of nutrient through organic and inorganic sources might be attributed to assemble of food and its subsequent partitioning to source to sink ratio and rapid expansion of dark green foliage, which could intercept and utilize more incident light energy in the production of carbohydrates through the process of photosynthesis (Agarwal et al., 2002 and Khanday et al., 2015).

\section{Straw yield (kg/ha)}

A perusal of data summarized in Table 1 revealed that straw yield was significantly affected by different treatments of INM. Treatment $\mathrm{T}_{6}(5 \mathrm{t} \mathrm{FYM}+25 \% \mathrm{~N}$ from FYM + $75 \% \mathrm{RDF}+$ Bio-fertilizer) recorded significantly higher straw yield $(8054 \mathrm{~kg} / \mathrm{ha})$. It was statistically at par with all other treatment except treatment $\mathrm{T}_{9}(5 \mathrm{t} \mathrm{FYM}+25 \%$ $\mathrm{N}$ from Neem Cake $+75 \% \mathrm{RDF}+\mathrm{Bio}-$ fertilizer) and $\mathrm{T}_{10}(50 \% \mathrm{~N}$ from FYM $+50 \%$ $\mathrm{N}$ from Castor Cake + Bio-fertilizer). 
Table.1 Effect of integrated nutrient management on growth and yield attributes as well as on economics of dual purpose fodder oat (Avena sativa L.)

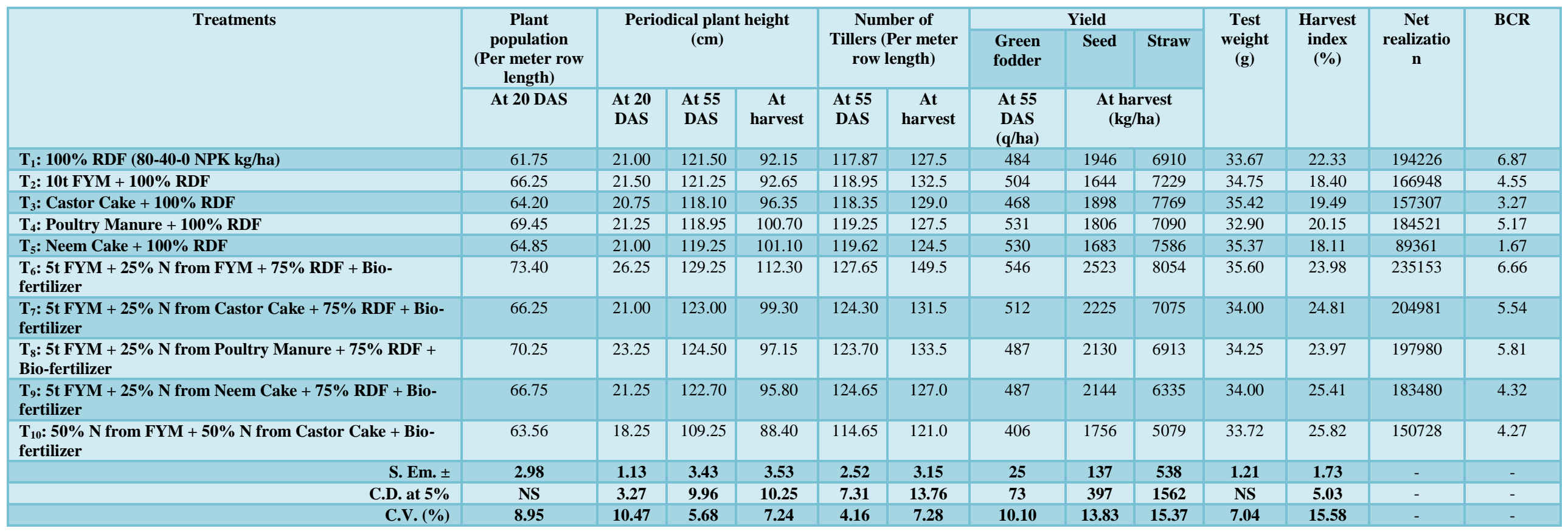

Fig.1 Seed, straw and green fodder yield of dual purpose fodder oat (Avena sativa L.) influenced by different INM treatments

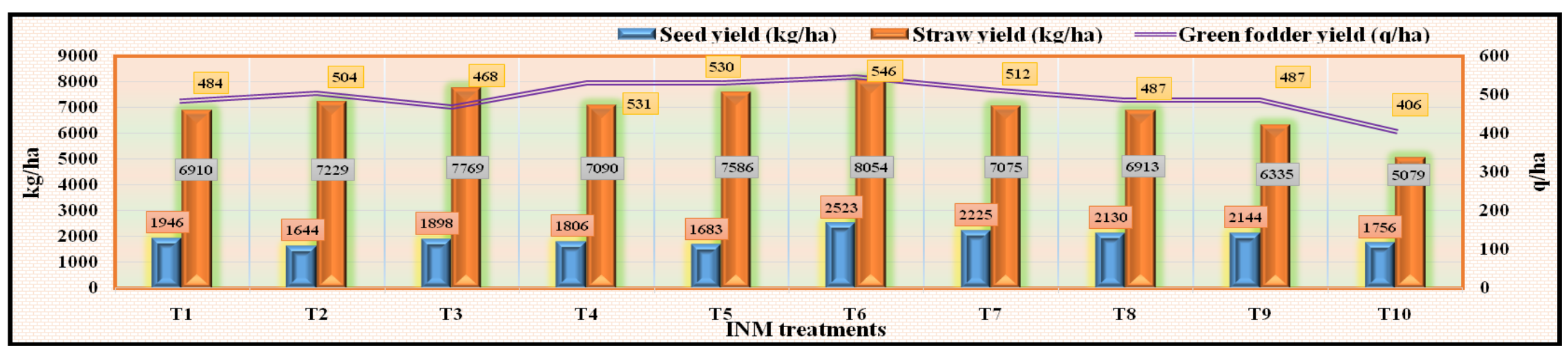


Application of $50 \% \mathrm{~N}$ from FYM $+50 \% \mathrm{~N}$ from Castor Cake + Bio-fertilizer $\left(\mathrm{T}_{10}\right)$ recorded significantly lower straw yield (5079 $\mathrm{kg} / \mathrm{ha})$ but it was at par with treatment $\mathrm{T}_{9}(5 \mathrm{t}$ $\mathrm{FYM}+25 \% \mathrm{~N}$ from Neem Cake $+75 \% \mathrm{RDF}$ + Bio-fertilizer). The positive influence of production of straw yield might be due to slow and steady supply of nutrients through combination of organic and inorganic fertilizer along with biofertilizer throughout the crop growth period improved suitable biomass production which resulted into higher straw yield(Meenaet al., 2007).

\section{Test weight (g)}

It was observed from data presented in Table 1 that test weight of oat was not found remarkably influenced due to INM treatments. Although the minor variations were noticed under different treatment wherein, treatment $\mathrm{T}_{6}(5 \mathrm{t} \mathrm{FYM}+25 \% \mathrm{~N}$ from $\mathrm{FYM}+75 \% \mathrm{RDF}+$ Bio-fertilizer) recorded numerically higher test weight $(35.60 \mathrm{~g})$ and numerically lower test weight (32.90 g) was reported in $\mathrm{T}_{4}$ (Poultry Manure $+100 \% \mathrm{RDF}$ ) treatment.

\section{Harvest index (\%)}

The statistical analysis of the data presented in Table 1 revealed that different treatments of INM was significantly influenced the harvest index of oat crop. Result of experiment revealed that application of 50\% $\mathrm{N}$ from $\mathrm{FYM}+50 \% \mathrm{~N}$ from Castor Cake + Bio-fertilizer $\left(\mathrm{T}_{10}\right)$ gave significantly higher harvest index $(25.82 \%)$ followed by $\left(\mathrm{T}_{9}\right) 5 \mathrm{t}$ $\mathrm{FYM}+25 \% \mathrm{~N}$ from Neem Cake $+75 \% \mathrm{RDF}$ + Bio-fertilizer. The lowest value of harvest index $(18.11 \%)$ was observed in treatment $\mathrm{T}_{5}$ (Neem Cake + 100\% RDF).

\section{Effect on economics}

Results revealed that maximum (235153
Rs./ha) net realization was recorded under treatment $\mathrm{T}_{6}(5 \mathrm{t} \mathrm{FYM}+25 \% \mathrm{~N}$ from FYM + $75 \%$ RDF + Bio-fertilizer) and BCR was recorded maximum 6.87 under application of $100 \%$ RDF $\left(\mathrm{T}_{1}\right)$ followed by $\left(\mathrm{T}_{6}\right)$ application of $5 \mathrm{t} \mathrm{FYM} \mathrm{+} \mathrm{25 \%} \mathrm{N} \mathrm{from} \mathrm{FYM} \mathrm{+} \mathrm{75 \%} \mathrm{RDF}$ + Bio-fertilizer as 6.66 .

In view of the results obtained from the investigation, it is concluded that dual purpose fodder oat ( $c v$. kent) should be fertilized with $5 \mathrm{t}$ FYM $+25 \% \mathrm{~N}$ from FYM $(20 \mathrm{~kg} \mathrm{~N} / \mathrm{ha})+75 \% \mathrm{RDF}(60 \mathrm{~kg} \mathrm{~N} / \mathrm{ha}+30 \mathrm{~kg}$ $\left.\mathrm{P}_{2} \mathrm{O}_{5}\right)+$ soil application of Bio-fertilizer (1 1/ha) for securing higher green fodder, seed and straw yield as well as higher net realization.

\section{References}

Agarwal, S. B., Tomar, S. S., Bhadauria, A. K., \&Kewat, M. L. (2002). Response of fodder oat (Avena sativa L.) to methods of Azotobacter inoculation under various levels of nitrogen. Annals of Agricultural Research, 23 (4), 692-696.

Alim, M. A. (2012). Effect of organic and inorganic sources and doses of nitrogen fertilizer on the yield of boro rice. Journal of Environmental Science and Natural Resources, 5 (1), 273-282.

Anonymous (2017). Department of Animal Husbandry and Dairying, 18th Livestock Census All India Report.

Chandra, S., and Ram, D. (2007). Effect of integrated nutrient management on yield and nutrient use efficiency in mustard. Indian Journal of Fertilizer, 3 (5), 5154.

Cochran, W. G., and Cox, G. M. (1967). Experimental Designs, John willey and Sons. Inc. New York, 546-568.

Jadav, V. M., Patel, P. M., Chaudhari, J. B., Patel, J. M., \&Chaudhari, P. P. (2018). Effect of integrated nutrient management on growth and yield of 
rabi forage maize (Zea mays L.). International Journal of Chemical Studies, 6 (1), 2160-216.

Jayanthi, C., Malarvizhi, P., Fazullah, Khan, A. K., and Chinnasamy, C. (2002). Integrated nutrient management in forage oat (Avenasativa L.). Indian Journal of Agronomy, 47 (1), 130-133.

Khanday, B. A., Samoon, A. S., Waseem, R., Khanday, J., and Bahar, F. A. (2015). Integrated nutrient management for seed production of oat (Avena sativa L.) under temperate conditions of Kashmir. International Journal of Agricultural Sciences, 5 (1), 145-147.

Meena, O., Khafi, H. R., Shekh, M. A., Mehta, A. C., and Davda, B. K. (2007). Effect of vermicompost and nitrogen on content, uptake and yield of rabi maize (Zea mays L.). Crop Research, 33 (1/3),
53-54.

Patel, J. B., Patel, V. J., and Patel, J. R. (2016). Influence of different methods of irrigation and nitrogen levels on crop growth rate and yield of maize (Zea mays L.). Indian journal of crop science, 1 (1-2), 175-177.

Rathod, P., and Dixit, S. (2019). Green fodder production: a manual for field functionaries.

Varma, N. K., Pandey, B. K., and Singhand, U. P. (2012). Effect of sowing dates in relation to integrated nitrogen management on growth, yield and quality of rabimaize (Zea mays L.). Journal of Animals and Plant Sciences, 22 (2), 324-329.

Virmani, S. M. (1994). UNCED Agena-21. Journal of Indian Society of Soil science, 42 (2), 516-522.

\section{How to cite this article:}

Vikram Shiyal, H. K. Patel, C. H. Raval, M. K. Rathwa, P. S. Patel and Patel, H. K. 2020. Fodder Yield and Economics as Influenced by Integrated Nutrient Management on Fodder Dual Purpose Oat (Avena sativa). Int.J.Curr.Microbiol.App.Sci. 9(11): 3752-3758. doi: https://doi.org/10.20546/ijcmas.2020.911.450 